\title{
Mutations of the TERT promoter are common in basal cell carcinoma and squamous cell carcinoma
}

\author{
Glynis A Scott ${ }^{1,2}$, Todd S Laughlin ${ }^{2}$ and Paul G Rothberg ${ }^{2}$ \\ ${ }^{1}$ Department of Dermatology, University of Rochester School of Medicine, Rochester, NY, USA and \\ ${ }^{2}$ Department of Pathology and Laboratory Medicine, University of Rochester School of Medicine, \\ Rochester, NY, USA
}

\begin{abstract}
Telomerase is frequently expressed in cancer and contributes to carcinogenesis. Two recent publications report the identification of a set of recurrent mutations in melanoma in the promoter of the telomerase reverse transcriptase gene (TERT) that appears to be the result of mutagenesis from ultraviolet (UV) radiation. Both groups reported that the mutations increase the transcription of TERT. This prompted our search for similar mutations in two other UV-related skin cancers, basal cell carcinoma, and squamous cell carcinoma. We found that the activating TERT promoter mutations reported in melanoma are also frequent in squamous cell carcinoma $(50 \%)$ and basal cell carcinoma, the latter including both sporadic tumors $(\mathbf{7 8} \%)$ and tumors from patients with nevoid basal cell carcinoma syndrome (68\%). These mutations were found in only 1 of 11 Bowen's disease (squamous cell carcinoma in situ) specimens, and in none of 15 non-malignant skin specimens and 57 blood specimens. The mutations were frequently homozygous or hemizygous, with little or no normal signal at the mutated positions. These data suggest that TERT promoter mutations are the most frequent putative oncogenic mutations in cutaneous cancer.

Modern Pathology (2014) 27, 516-523; doi:10.1038/modpathol.2013.167; published online 13 September 2013
\end{abstract}

Keywords: basal cell carcinoma; mutation; squamous cell carcinoma; telomerase; TERT; ultraviolet radiation

Basal cell carcinoma and squamous cell carcinoma are the most common cancers in light-skinned individuals, and account for the majority of all human cancers. ${ }^{1-3}$ Both tumors are strongly associated with chronic ultraviolet (UV) radiation exposure and occur primarily, but not exclusively, on sun-exposed areas of the body. ${ }^{4-8}$ The most commonly mutated gene in basal cell carcinoma and squamous cell carcinoma is TP53, with the majority of mutations consistent with UV as the mutagen. ${ }^{9,10}$ Inactivating mutations in the $P T C H$ gene, the gene responsible for nevoid basal cell carcinoma syndrome, have also been identified in sporadic basal cell carcinoma, also with evidence for UV causation. ${ }^{11,12}$

Telomerase is a ribonucleoprotein that adds telomeric sequences (TTAGGG hexamers) to the ends of chromosomes. Increased telomerase activity

Correspondence: Dr PG Rothberg, Department of Pathology and Laboratory Medicine, University of Rochester Medical Center, 601 Elmwood Avenue, Box 626, Rochester, NY 14642, USA.

E-mail: paul_rothberg@urmc.rochester.edu

Received 31 May 2013; revised 29 July 2013; accepted 30 July 2013; published online 13 September 2013 is thought to promote carcinogenesis and immortalization of cells by preventing senescence induced by telomere shortening. ${ }^{13}$ Telomerase activity is not detectable in the majority of normal skin samples tested by the telomerase rapid amplification protocol, whereas basal cell carcinoma, squamous cell carcinoma, and some premalignant lesions, including Bowen's disease and actinic keratosis, have detectable telomerase activity. ${ }^{14-16}$

Horn et $a 1^{17}$ and Huang et $a 1^{18}$ recently reported the frequent occurrence of a set of $\mathrm{C}>\mathrm{T}$ mutations in the promoter of the telomerase reverse transcriptase gene (TERT) in melanoma. These mutations were consistent with UV-induced mutagenesis, and created binding sites for the ETS/TCF transcription factors. Both groups also reported that the mutations caused a 2- to 4-fold increase in transcriptional activity of the promoter, using reporter gene assays. These findings prompted us to investigate the possibility that similar mutations would be found in other cutaneous cancers in which UV has a causal role, basal cell carcinoma and squamous cell carcinoma. We analyzed sporadic basal cell carcinoma and basal cell carcinoma from patients with nevoid basal cell carcinoma syndrome, 
squamous cell carcinoma, as well as its precursor lesion Bowen's disease, for mutations in the TERT promoter. We show that a high percentage of basal cell and squamous cell carcinomas carry mutations in the TERT promoter, that the mutations are consistent with UV exposure as the mutagen, and that many of the mutations are homozygous. Because of the high prevalence of basal cell and squamous cell carcinomas in the population, TERT promoter mutations may represent one of the most common mutations in human cancer.

\section{Materials and methods}

\section{Specimen Selection}

Cutaneous tumors, normal skin, benign skin lesions, and anonymized DNA from blood specimens were obtained according to a protocol approved by the University of Rochester Research Subject Review Board. Formalin-fixed paraffin-embedded samples were retrieved from the Surgical Pathology Division of the Department of Pathology, University of Rochester. Samples in which tumor cells occupied $>50 \%$ of the paraffin block were used for TERT promoter mutation analysis, without microdissection. All samples were biopsied from 2011 to 2013, with the exception of two tumor samples from a patient with nevoid basal cell carcinoma syndrome which were obtained between 2007 and 2010 . Tables 1-4 summarize the demographic information of the patients whose tumors were analyzed. A total of 18 patients with sporadic basal cell carcinoma ( $n=23$ tumors, Table 1), 4 patients with nevoid basal cell carcinoma syndrome ( $n=19$ tumors, Table 2), 19 subjects with squamous cell carcinoma $(n=26$ tumors, Table 3), and 11 subjects with Bowen's disease tumors $(n=11$, Table 4$)$ were tested. Controls included 57 anonymized DNAs from blood specimens that had been collected for unrelated genetic studies, and 15 benign skin specimens (Table 5) with a variety of diagnoses including 7 seborrheic keratosis, 2 hemangiomas, 2 histologically normal skin, 2 scar tissue (cicatrix), and 1 each of lymphoid hyperplasia and soft fibroma.

\section{DNA Preparation, PCR, and Sequencing}

Material was cut from the paraffin block of each sample $(30 \mu \mathrm{M})$ and genomic DNA was purified using the QIAamp system (Qiagen, Valencia, CA, USA) according to the manufacturer's protocol. PCR was performed in a total volume of $12 \mu \mathrm{l}$ with primers at a final concentration of $1 \mu \mathrm{M}$ each, $50 \mu \mathrm{M}$ of each dNTP, 5\% dimethylsulfoxide, 0.75 units of HotStar Taq DNA polymerase, $1.2 \mu \mathrm{l}$ of the $10 \mathrm{X}$ buffer provided by the enzyme manufacturer (Qiagen) and 50-100 ng of template DNA. The genespecific parts of the upstream and downstream primers were 5'-GCCGGGCTCCCAGTGGATTCG-3' and 5'-GCTTCCCACGTGCGCAGCAGGA-3', respectively. The PCR primers were synthesized with M13 tail sequences appended to the $5^{\prime}$-end to facilitate sequencing, and were targeted to amplify sequence

Table 1 Sporadic basal cell carcinomas: mutations and demographic information

\begin{tabular}{|c|c|c|c|c|}
\hline Specimen no. BCC- & Classic mutation $^{\mathrm{a}}$ & Other mutations ${ }^{\mathrm{a}}$ & Age/gender & Site \\
\hline 1 & $-146 \mathrm{C}>\mathrm{T}$ & $-101 \mathrm{C}>\mathrm{T}$, heterozygous & $51 / \mathrm{M}$ & Nose \\
\hline $2 \mathrm{~A}^{\mathrm{b}}$ & $-138 /-139 \mathrm{CC}>\mathrm{TT}$ & $\mathrm{N}$ & $81 / \mathrm{M}$ & Cheek \\
\hline $2 \mathrm{~B}^{\mathrm{b}}$ & $\mathrm{N}$ & $\mathrm{N}$ & $81 / \mathrm{M}$ & Back \\
\hline 3 & $-138 /-139 \mathrm{CC}>\mathrm{TT}$ & $\mathrm{N}$ & $81 / \mathrm{M}$ & Neck \\
\hline 4 & $-146 \mathrm{C}>\mathrm{T}$ & $\mathrm{N}$ & $48 / \mathrm{F}$ & Neck \\
\hline 5 & $-146 \mathrm{C}>\mathrm{T}$ & $\mathrm{N}$ & $82 / \mathrm{M}$ & Forehead \\
\hline $6 A^{b}$ & $-124 /-125 \mathrm{CC}>\mathrm{TT}$ & $-101 \mathrm{C}>\mathrm{T}$ & $71 / \mathrm{M}$ & Shoulder \\
\hline $6 \mathrm{~B}^{\mathrm{b}}$ & $\mathrm{N}$ & $-159 \mathrm{C}>\mathrm{T}+-101 \mathrm{C}>\mathrm{T}$ both heterozygous & $71 / \mathrm{M}$ & Nose \\
\hline $6 \mathrm{C}^{\mathrm{b}}$ & $-138 /-139 \mathrm{CC}>\mathrm{TT}+-124 /-125 \mathrm{CC}>\mathrm{TT}$ & $-100 /-101 \mathrm{CC}>\mathrm{TT}$ & $71 / \mathrm{M}$ & Nose \\
\hline $6 \mathrm{D}^{\mathrm{b}}$ & $\mathrm{N}$ & $-111 \mathrm{C}>\mathrm{T}$ & $71 / \mathrm{M}$ & Temple \\
\hline 7 & $-124 \mathrm{C}>\mathrm{T}$, heterozygous & $\mathrm{N}$ & $63 / \mathrm{M}$ & Cheek \\
\hline 8 & $-124 /-125 \mathrm{CC}>\mathrm{TT}$ & $-145 \mathrm{C}>\mathrm{T}$ & $92 / \mathrm{M}$ & Neck \\
\hline 9 & $-146 \mathrm{C}>\mathrm{T}$, heterozygous & $\mathrm{N}$ & $71 / \mathrm{F}$ & Temple \\
\hline 10 & $-146 \mathrm{C}>\mathrm{T}$ & $\mathrm{N}$ & $91 / \mathrm{M}$ & Ear \\
\hline 11 & $-146 \mathrm{C}>\mathrm{T}$ & $\mathrm{N}$ & $63 / \mathrm{M}$ & Shoulder \\
\hline 12 & $-138 /-139 \mathrm{CC}>\mathrm{TT}$ & $-101 \mathrm{C}>\mathrm{T}$ & $70 / \mathrm{M}$ & Lip \\
\hline $13 \mathrm{~A}^{\mathrm{b}}$ & $-124 \mathrm{C}>\mathrm{T}$ & $\mathrm{N}$ & $76 / \mathrm{M}$ & Ear \\
\hline $13 \mathrm{~B}^{\mathrm{b}}$ & $-124 \mathrm{C}>\mathrm{T}$ & $\mathrm{N}$ & $76 / \mathrm{M}$ & Back \\
\hline 14 & $\mathrm{~N}$ & $\mathrm{~N}$ & $47 / \mathrm{F}$ & Nose \\
\hline 15 & $-138 /-139 \mathrm{CC}>\mathrm{TT}$ & $\mathrm{N}$ & $66 / \mathrm{M}$ & Nose \\
\hline 16 & $-146 \mathrm{C}>\mathrm{T}$ & $-101 \mathrm{C}>\mathrm{T}$, heterozygous & $66 / \mathrm{M}$ & Temple \\
\hline 17 & $\mathrm{~N}$ & $\mathrm{~N}$ & $82 / \mathrm{M}$ & Shoulder \\
\hline 18 & $-138 /-139 \mathrm{CC}>\mathrm{TT}$, heterozygous & $\mathrm{N}$ & 82/M & Ear \\
\hline
\end{tabular}

Abbreviation: N, no mutation identified in this category.

a All mutations were homozygous unless indicated otherwise. Classic mutations are the recurrent mutations in the TERT promoter discovered in melanoma $(-124 \mathrm{C}>\mathrm{T},-146 \mathrm{C}>\mathrm{T}$, and the double mutations $-124 /-125 \mathrm{CC}>\mathrm{TT}$ and $-138 /-139 \mathrm{CC}>\mathrm{TT}) .{ }^{17,18}$

${ }^{\mathrm{b}}$ Letter subcodes in the first column indicate tumors taken from the same patient, on the same day. 
Table 2 Nevoid basal cell carcinoma syndrome: mutations and demographic information

\begin{tabular}{|c|c|c|c|c|}
\hline Specimen no. NBCCS- & Classic mutation $^{\mathrm{a}}$ & Other mutations ${ }^{\mathrm{a}}$ & Age/gender & Site \\
\hline \multicolumn{5}{|l|}{ Subject 1} \\
\hline $1 A^{b}$ & $\mathrm{~N}$ & $-125 /-126$, heterozygous & $52 / \mathrm{F}$ & Eyelid \\
\hline $1 \mathrm{~B}^{\mathrm{b}}$ & $-124 /-125 \mathrm{CC}>\mathrm{TT}$ & $-101 \mathrm{C}>\mathrm{T}$ & $52 / \mathrm{F}$ & Ear \\
\hline $2 \mathrm{~A}^{\mathrm{b}}$ & $-146 \mathrm{C}>\mathrm{T}$, heterozygous & $-101 \mathrm{C}>\mathrm{T}$, heterozygous & $52 / \mathrm{F}$ & Scalp \\
\hline $2 \mathrm{~B}^{\mathrm{b}}$ & $\mathrm{N}$ & $\mathrm{N}$ & $52 / \mathrm{F}$ & Scalp \\
\hline 3 & $\mathrm{~N}$ & $\mathrm{~N}$ & $52 / \mathrm{F}$ & Scalp \\
\hline \multicolumn{5}{|l|}{ Subject 2} \\
\hline $1 \mathrm{~A}^{\mathrm{b}}$ & $-146 \mathrm{C}>\mathrm{T}$ & $\mathrm{N}$ & $81 / \mathrm{F}$ & Neck \\
\hline $1 \mathrm{~B}^{\mathrm{b}}$ & $-146 \mathrm{C}>\mathrm{T}$ & $\mathrm{N}$ & $81 / \mathrm{F}$ & Scalp \\
\hline $2 \mathrm{~A}^{\mathrm{b}}$ & $\mathrm{N}$ & $\mathrm{N}$ & $81 / \mathrm{F}$ & Scalp \\
\hline $2 \mathrm{~B}^{\mathrm{b}}$ & $\mathrm{N}$ & $\mathrm{N}$ & $81 / \mathrm{F}$ & Scalp \\
\hline $2 \mathrm{C}^{\mathrm{b}}$ & $-138 /-139 \mathrm{CC}>\mathrm{TT}$ & $-101 \mathrm{C}>\mathrm{T}$ & $81 / \mathrm{F}$ & Chin \\
\hline \multicolumn{5}{|l|}{ Subject 3} \\
\hline $1 \mathrm{~A}^{\mathrm{b}}$ & $-124 \mathrm{C}>\mathrm{T}$ & $-100 \mathrm{C}>\mathrm{T}$ & $48 / \mathrm{F}$ & Neck \\
\hline $1 \mathrm{~B}^{\mathrm{b}}$ & $-124 \mathrm{C}>\mathrm{T}$ & $\mathrm{N}$ & $48 / \mathrm{F}$ & Shoulder \\
\hline $1 \mathrm{C}^{\mathrm{b}}$ & $-124 \mathrm{C}>\mathrm{T}$ & $\mathrm{N}$ & $48 / \mathrm{F}$ & Arm \\
\hline $1 D^{b}$ & $-146 \mathrm{C}>\mathrm{T}$ & $\mathrm{N}$ & $48 / \mathrm{F}$ & Back \\
\hline 2 & $\mathrm{~N}$ & $\mathrm{~N}$ & $48 / \mathrm{F}$ & Nose \\
\hline $3 \mathrm{~A}^{\mathrm{b}}$ & $-124 \mathrm{C}>\mathrm{T}$ & $\mathrm{N}$ & $48 / \mathrm{F}$ & Back \\
\hline $3 \mathrm{~B}^{\mathrm{b}}$ & $-124 \mathrm{C}>\mathrm{T}$ & $\mathrm{N}$ & $48 / \mathrm{F}$ & Back \\
\hline \multicolumn{5}{|l|}{ Subject 4} \\
\hline 1 & $-124 \mathrm{C}>\mathrm{T}$ & $\mathrm{N}$ & $49 / \mathrm{M}$ & Leg \\
\hline 2 & $-124 /-125 \mathrm{CC}>\mathrm{TT}$ & $\mathrm{N}$ & $49 / \mathrm{M}$ & Ear \\
\hline
\end{tabular}

Abbreviation: N, no mutation identified in this category.

aAll mutations were homozygous unless indicated otherwise. Classic mutations are the recurrent mutations in the TERT promoter discovered in melanoma $(-124 \mathrm{C}>\mathrm{T},-146 \mathrm{C}>\mathrm{T}$, and the double mutations $-124 /-125 \mathrm{CC}>\mathrm{TT}$ and $-138 /-139 \mathrm{CC}>\mathrm{TT}) .{ }^{17,18}$

${ }^{b}$ Letter subcodes in the first column indicate tumors taken from the same patient, on the same day.

from -270 to $-50 \mathrm{bps}$ upstream from the initiator ATG within the promoter region of the TERT gene. The reactions were cycled 42 times between $95^{\circ} \mathrm{C}$ for $15 \mathrm{~s}, 63^{\circ} \mathrm{C}$ for $15 \mathrm{~s}$, and $72^{\circ} \mathrm{C}$ for $45 \mathrm{~s}$, preceded by $15 \mathrm{~min}$ at $95{ }^{\circ} \mathrm{C}$, and followed by $5 \mathrm{~min}$ at $72{ }^{\circ} \mathrm{C}$. The primers were purchased from Integrated DNA Technologies (Coralville, IA). The 306-bp amplicon (including tails) was treated with ExoSap (Amersham Biosciences, Piscataway, NJ, USA) to remove the primers and dNTPs; then sequenced using the M13 tails as sequencing primers and Applied Biosystems (ABI, Foster City, CA, USA) BigDye Terminator v.3.1 chemistry. The sequencing reactions were purified using the CleanSeq system (Agencourt Bioscience, Beverly, MA, USA) and then resolved by capillary electrophoresis on the ABI 3500XL Genetic Analyzer. All of the mutations were confirmed by repeat analysis starting with the PCR step.

\section{Statistical Analysis}

Groups were compared for mutation frequencies using the $\chi^{2}$ statistics. $P<0.05$ was considered as significant.

\section{Results}

\section{TERT Promoter Mutation Analysis}

We analyzed squamous cell carcinoma $(n=26)$, Bowen's disease $(n=11)$, sporadic basal cell carcinoma $(n=23)$, and 19 basal cell carcinomas from 4 patients with nevoid basal cell carcinoma syndrome. Patients with nevoid basal cell carcinoma syndrome were diagnosed based on the characteristic clinical features, including the presence of multiple basal cell carcinomas starting at a young age. Figure 1 shows the representative photomicrographs of hematoxylin and eosin-stained sections of the tumors studied. We obtained sequence from -270 to -50 bps upstream from the initiator ATG, which includes all of the recurrent TERT promoter mutations described in melanoma. ${ }^{17,18}$ These mutations include: $-124 \mathrm{C}>\mathrm{T}$ (chr 5: 1295228$), \quad-146 \mathrm{C}>\mathrm{T}$ (1295250), and the double mutations -124/ - 125CC > TT (1295228_1295229) and - 138/ -139CC > TT (1 $295242 \_1295243$ ). We will refer to this set of recurrent mutations as the classic mutations. A full description of the mutations found in each specimen, and demographic information for each patient, is presented in Tables 1-5. The results are summarized in Table 6.

Classic mutations were found in 18/23 sporadic basal cell carcinomas from a total of 18 patients (Table 1), 13/19 basal cell carcinomas from 4 patients with nevoid basal cell carcinoma syndrome (Table 2), 13/26 squamous cell carcinomas from a total of 19 patients (Table 3), and 1/11 Bowen's disease specimens from a total of 11 patients (Table 4). Figure 2 shows Sanger sequencing data for representative tumors. As shown in Figure 2, detailed in Tables 1-4, and summarized in Table 6, many of the mutations were homozygous, with little 
Table 3 Squamous cell carcinomas: mutations and demographic information

\begin{tabular}{|c|c|c|c|c|}
\hline Specimen no. SCC- & Classic mutation ${ }^{\mathrm{a}}$ & Other mutations ${ }^{\mathrm{a}}$ & Age/Gender & Site \\
\hline $1 A^{b}$ & $\mathrm{~N}$ & $\mathrm{~N}$ & $86 / \mathrm{F}$ & Shin \\
\hline $1 \mathrm{~B}^{\mathrm{b}}$ & $\mathrm{N}$ & $\mathrm{N}$ & $86 / \mathrm{F}$ & Shin \\
\hline 2 & $\mathrm{~N}$ & $\mathrm{~N}$ & $74 / \mathrm{M}$ & Arm \\
\hline $3 A^{b}$ & $-146 \mathrm{C}>\mathrm{T}$ & $\mathrm{N}$ & $90 / \mathrm{F}$ & Scalp \\
\hline $3 \mathrm{~B}^{\mathrm{b}}$ & $-146 \mathrm{C}>\mathrm{T}$ & $-126 \mathrm{C}>\mathrm{T}$ & $90 / \mathrm{F}$ & Scalp \\
\hline $3 C^{b}$ & $-146 \mathrm{C}>\mathrm{T}$ & $-126 \mathrm{C}>\mathrm{T}$ & $90 / \mathrm{F}$ & Scalp \\
\hline 4 & $-146 \mathrm{C}>\mathrm{T}$ & $\mathrm{N}$ & $55 / \mathrm{M}$ & Ear \\
\hline 5 & $\mathrm{~N}$ & $-150 \mathrm{C}>\mathrm{T}$ & 71/M & Temple \\
\hline 6 & $-138 /-139 \mathrm{CC}>\mathrm{TT}$, heterozygous & $\mathrm{N}$ & $79 / \mathrm{F}$ & Arm \\
\hline 7 & $\mathrm{~N}$ & $\mathrm{~N}$ & 71/M & Scalp \\
\hline 8 & $\mathrm{~N}$ & $-126 /-127 \mathrm{CC}>\mathrm{TT}$, heterozygous & $61 / \mathrm{M}$ & Back \\
\hline 9 & $-146 \mathrm{C}>\mathrm{T}$, heterozygous & $\mathrm{N}$ & 79/M & Ear \\
\hline 10 & $-124 \mathrm{C}>\mathrm{T}$ & $\mathrm{N}$ & $62 / \mathrm{M}$ & Cheek \\
\hline $11 \mathrm{~A}^{\mathrm{b}}$ & $-138 /-139 \mathrm{CC}>\mathrm{TT}$ & $\mathrm{N}$ & $52 / \mathrm{M}$ & Scalp \\
\hline $11 \mathrm{~B}^{\mathrm{b}}$ & $\mathrm{N}$ & $\mathrm{N}$ & $52 / \mathrm{M}$ & Shin \\
\hline $11 C^{b}$ & $\mathrm{~N}$ & $\mathrm{~N}$ & $52 / \mathrm{M}$ & Thigh \\
\hline $11 \mathrm{D}^{\mathrm{b}}$ & $\mathrm{N}$ & $\mathrm{N}$ & $52 / \mathrm{M}$ & Shin \\
\hline $12 \mathrm{~A}^{\mathrm{b}}$ & $-124 \mathrm{C}>\mathrm{T}$, heterozygous & $\mathrm{N}$ & $76 / \mathrm{M}$ & Jaw \\
\hline $12 \mathrm{~B}^{\mathrm{b}}$ & $-146 \mathrm{C}>\mathrm{T}$, heterozygous & $\mathrm{N}$ & $76 / \mathrm{M}$ & Arm \\
\hline 13 & $\mathrm{~N}$ & $\mathrm{~N}$ & $63 / \mathrm{F}$ & Arm \\
\hline 14 & $\mathrm{~N}$ & $\mathrm{~N}$ & 76/M & Cheek \\
\hline 15 & $\mathrm{~N}$ & $\mathrm{~N}$ & $63 / \mathrm{M}$ & Ear \\
\hline $16^{\mathrm{C}}$ & $-146 \mathrm{C}>\mathrm{T}$ & $\mathrm{N}$ & 70/M & Cheek \\
\hline $17^{\mathrm{C}}$ & $\mathrm{N}$ & $-101 \mathrm{C}>\mathrm{T}$, heterozygous & $65 / \mathrm{M}$ & Shoulder \\
\hline $18^{\mathrm{C}}$ & $-124 \mathrm{C}>\mathrm{T}$, heterozygous & $\mathrm{N}$ & $81 / \mathrm{M}$ & Forearm \\
\hline $19^{\mathrm{C}}$ & $-124 \mathrm{C}>\mathrm{T}$ & $\mathrm{N}$ & $67 / \mathrm{M}$ & Lip \\
\hline
\end{tabular}

Abbreviation: N, no mutation identified in this category.

a All mutations were homozygous unless indicated otherwise. Classic mutations are the recurrent mutations in the TERT promoter discovered in melanoma $(-124 \mathrm{C}>\mathrm{T},-146 \mathrm{C}>\mathrm{T}$, and the double mutations $-124 /-125 \mathrm{CC}>\mathrm{TT}$ and $-138 /-139 \mathrm{CC}>\mathrm{TT}){ }^{17,18}$

${ }^{b}$ Letter subcodes in the first column indicate tumors taken from the same patient, on the same day.

CPoorly differentiated SCC.

Table 4 Bowen's disease (squamous cell carcinoma in situ): mutations and demographic information

\begin{tabular}{|c|c|c|c|c|}
\hline $\begin{array}{l}\text { Specimen } \\
\text { no. BD- }\end{array}$ & $\begin{array}{c}\text { Classic } \\
\text { mutation }^{\mathrm{a}}\end{array}$ & Other mutations ${ }^{\mathrm{a}}$ & $\begin{array}{c}\text { Age/ } \\
\text { Gender }\end{array}$ & Site \\
\hline 1 & $\mathrm{~N}$ & $\mathrm{~N}$ & $79 / F$ & Leg \\
\hline 2 & $\mathrm{~N}$ & $\mathrm{~N}$ & $77 / \mathrm{F}$ & Arm \\
\hline 3 & $\mathrm{~N}$ & $\mathrm{~N}$ & $88 / F$ & Shin \\
\hline 4 & $\mathrm{~N}$ & $\mathrm{~N}$ & $82 / \mathrm{M}$ & Shoulder \\
\hline 5 & $\mathrm{~N}$ & $\mathrm{~N}$ & $63 / \mathrm{F}$ & Thigh \\
\hline 6 & $\mathrm{~N}$ & $\mathrm{~N}$ & $55 / \mathrm{M}$ & Thigh \\
\hline 7 & $\mathrm{~N}$ & $\mathrm{~N}$ & $87 / \mathrm{F}$ & Thigh \\
\hline 8 & $-146 \mathrm{C}>\mathrm{T}$ & $\mathrm{N}$ & $62 / \mathrm{M}$ & Cheek \\
\hline 9 & $\mathrm{~N}$ & $\mathrm{~N}$ & $58 / \mathrm{F}$ & Shoulder \\
\hline 10 & $\mathrm{~N}$ & $\mathrm{~N}$ & $71 / \mathrm{M}$ & Temple \\
\hline 11 & $\mathrm{~N}$ & $\begin{array}{c}-101 \mathrm{C}>\mathrm{T}, \\
\text { heterozygous }\end{array}$ & $61 / \mathrm{M}$ & Neck \\
\hline
\end{tabular}

Abbreviation: N, no mutation identified in this category.

${ }^{a}$ All mutations were homozygous unless indicated otherwise. Classic mutations are the recurrent mutations in the TERT promoter discovered in melanoma $(-124 \mathrm{C}>\mathrm{T},-146 \mathrm{C}>\mathrm{T}$, and the double mutations $-124 /-125 \mathrm{CC}>\mathrm{TT}$ and $-138 /-139 \mathrm{CC}>\mathrm{TT}) .{ }^{17,18}$

or no signal from the normal nucleotide at the position of the mutation. None of the classic mutations was found in a survey of 57 anonymized blood specimens that had been collected for unrelated genetic studies (data not shown) or in 15 benign skin specimens (Table 5). Previous work on
TERT promoter mutations in melanoma noted that the classic mutations were mutually exclusive, with no tumor having more than one of the recurrent C $>$ T or CC $>$ TT mutations. ${ }^{17,18}$ Our results followed this pattern of mutual exclusivity with one exception, a sporadic basal cell carcinoma (BCC 6C) that had both the $-138 /-139 \mathrm{CC}>\mathrm{TT}$ and $-124 /-125 \mathrm{CC}>\mathrm{TT}$ mutations, as well as a $-100 /-101 \mathrm{CC}>\mathrm{TT}$ mutation, all homozygous (Figure 2c). The $-57 \mathrm{~A}>\mathrm{C}$ TERT promoter mutation that co-segregated with disease in a pedigree with familial melanoma ${ }^{17}$ was not found in any of the specimens.

For those patients with multiple tumors $(n=11)$, three were concordant for the classic mutations (same mutation in all tumors), and eight were nonconcordant, with at least some diversity for the mutations among the tumors (see Tables 1-3). Of the three concordant sets, two were sets of only two tumors, limiting the opportunity to find different mutations. Thus, the mutations appeared to be independent events as expected for independent primary tumors. The frequency of mutations in sporadic basal cell carcinoma and nevoid basal cell carcinoma syndrome was similar, with all four patients with the inherited form exhibiting TERT promoter mutations in two or more of the tumors. 
Table 5 Non-malignant skin controls: mutations and demographic information

\begin{tabular}{|c|c|c|c|c|c|}
\hline Specimen no. Cntrl- & Diagnosis & Classic mutation $^{\mathrm{a}}$ & Other mutations ${ }^{\mathrm{a}}$ & Age/gender & Site \\
\hline 1 & Lymphoid hyperplasia & $\mathrm{N}$ & $\mathrm{N}$ & $35 / \mathrm{M}$ & Neck \\
\hline 2 & Normal & $\mathrm{N}$ & $\mathrm{N}$ & $46 / \mathrm{M}$ & Shoulder \\
\hline 3 & Normal & $\mathrm{N}$ & $\mathrm{N}$ & $27 / \mathrm{F}$ & Back \\
\hline 4 & SK & $\mathrm{N}$ & $\mathrm{N}$ & $55 / \mathrm{M}$ & Shoulder \\
\hline 5 & SK & $\mathrm{N}$ & $\mathrm{N}$ & $71 / \mathrm{M}$ & Temple \\
\hline $6 A^{b}$ & SK & $\mathrm{N}$ & $\mathrm{N}$ & $50 / \mathrm{M}$ & Penis \\
\hline $6 \mathrm{~B}^{\mathrm{b}}$ & SK & $\mathrm{N}$ & $\mathrm{N}$ & $50 / \mathrm{M}$ & Shoulder \\
\hline 7 & Cicatrix & $\mathrm{N}$ & $\mathrm{N}$ & $70 / \mathrm{F}$ & Abdomen \\
\hline 8 & Hemangioma & $\mathrm{N}$ & $-126 \mathrm{C}>\mathrm{T}$, heterozygous & $51 / \mathrm{F}$ & Chest \\
\hline 9 & Cicatrix & $\mathrm{N}$ & $\mathrm{N}$ & $31 / \mathrm{F}$ & Shoulder \\
\hline 10 & Soft fibroma & $\mathrm{N}$ & $\mathrm{N}$ & $69 / \mathrm{F}$ & Arm \\
\hline 11 & SK & $\mathrm{N}$ & $\mathrm{N}$ & $82 / \mathrm{F}$ & Arm \\
\hline 12 & Hemangioma & $\mathrm{N}$ & $\mathrm{N}$ & $53 / \mathrm{F}$ & Leg \\
\hline $13 \mathrm{~A}^{\mathrm{b}}$ & SK & $\mathrm{N}$ & $\mathrm{N}$ & $55 / \mathrm{M}$ & Chest \\
\hline $13 \mathrm{~B}^{\mathrm{b}}$ & SK & $\mathrm{N}$ & $\mathrm{N}$ & $55 / \mathrm{M}$ & Neck \\
\hline
\end{tabular}

Abbreviations: SK, seborrheic keratosis; N, no mutation identified in this category.

${ }^{a}$ All mutations were homozygous unless indicated otherwise. Classic mutations are the recurrent mutations in the TERT promoter discovered in melanoma $(-124 \mathrm{C}>\mathrm{T},-146 \mathrm{C}>\mathrm{T}$, and the double mutations $-124 /-125 \mathrm{CC}>\mathrm{TT}$ and $-138 /-139 \mathrm{CC}>\mathrm{TT}) .{ }^{17,18}$

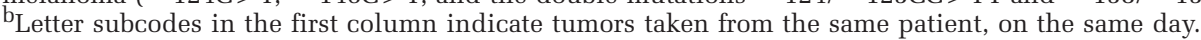

\section{Other Mutations}

In addition to the classic mutations identified in melanoma, $\mathrm{C}>\mathrm{T}$ mutations were identified at positions $-100,-101,-111,-126,-145,-150$, and - 159 (see Tables 1-5). Dual CC $>$ TT mutations were also found at $-100 /-101,-125 /-126$, and $-126 /-127$. As for the classic mutations, many of these non-classic mutations were also homozygous (Table 6). These mutations differ from the classic mutations in that they do not create a putative TCF binding motif. These non-classic mutations were found in some tumors concurrently with a classic mutation (12 cases) and in some independently (7 cases) (Table 6). Only one non-classic mutation was found in more than two cases, $\mathrm{C}>\mathrm{T}$ at -101 (Figure 2b), which was found in eleven cases, but was accompanied by a classic mutation in all but three cases. Mutations at positions -101 and -126 , as well as several other positions in the TERT promoter, have been described in melanoma. ${ }^{17}$ One of the benign skin lesions, a hemangioma, had a heterozygous $-126 \mathrm{C}>\mathrm{T}$ mutation (Table 5).

\section{Discussion}

Maintenance of telomere length, most frequently by activation of telomerase, is a hallmark of cancer. ${ }^{19}$ The recent discovery of activating mutations in the promoter of the TERT gene, at first in melanoma ${ }^{17,18}$ and then in several other malignancies, ${ }^{18,20}$ suggests that these mutations may be one of the most common mechanisms contributing to maintenance of telomeres in cancer. We examined mutations in the TERT promoter in two UV-related skin cancers, basal cell carcinoma, and squamous cell carcinoma, and in a cohort of patients with basal cell carcinomas arising in association with nevoid basal cell carcinoma syndrome. We detected promoter mutations associated with TERT gene activation to be very frequent in these cancers, particularly in basal cell carcinomas (74\%). While squamous cell carcinomas also displayed a high frequency of mutations $(50 \%)$, mutations were significantly more frequent in the basal cell tumors $(P=0.046)$. Mutations in sporadic basal cell carcinomas $(78 \%)$ and tumors from individuals with nevoid basal cell carcinoma syndrome (68\%) were similar. The classic TERT promoter mutations were more frequent in squamous cell carcinomas compared with the precursor lesion Bowen's disease $(P=0.019)$. While the poorly differentiated squamous cell carcinomas were more likely to have the classic mutations than the well-differentiated tumors, this difference did not reach statistical significance, possibly due to the small sample size. A recent publication found a TERT promoter mutation in one of the five skin squamous cell carcinomas studied. ${ }^{20}$

All mutations identified were $\mathrm{C}>\mathrm{T}$ substitutions or $\mathrm{CC}>\mathrm{TT}$ double substitutions at dipyrimidine sites, characteristic of mutations associated with exposure to $\mathrm{UV}^{21}$ This includes the classic mutations ${ }^{17,18}$ as well as the non-classic mutations. We speculate that most of the non-classic mutations were UV-induced passenger mutations that were present in the skin cells before tumorigenesis, with the possible exception of the $-101 \mathrm{C}>\mathrm{T}$ mutation that was found more frequently than the other nonclassic mutations. The non-classic mutations are likely not pathogenic because they do not create the TCF binding motif (TTCCGG) that is created by the classic mutations, they co-occur frequently with the classic mutations, and with the exception of $-101 \mathrm{C}>\mathrm{T}$, are not recurrent. Considering the 

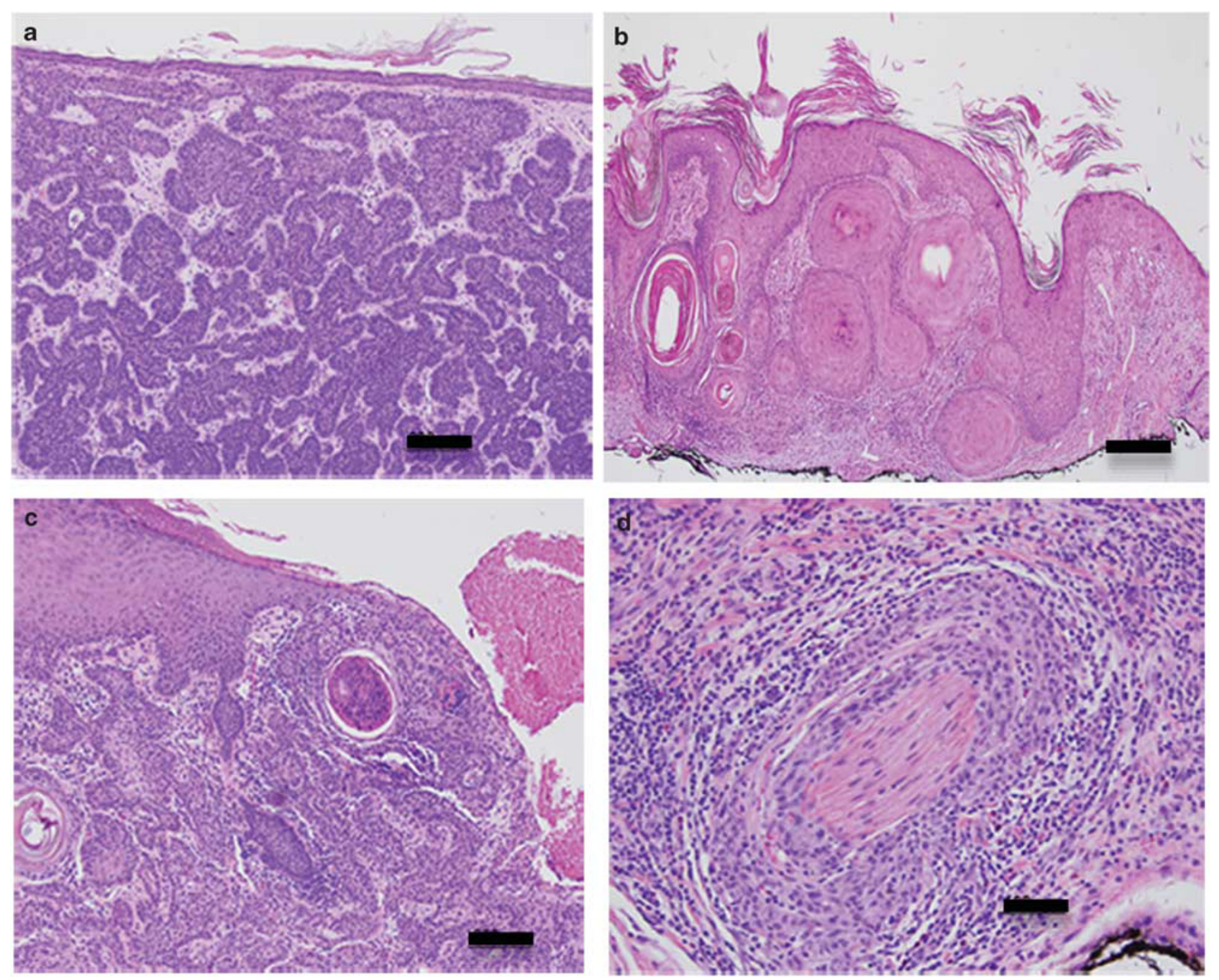

Figure 1 Representative tumors used in the study. Hematoxylin and eosin-stained sections of representative tumors used in these studies. (a) Basal cell carcinoma ( $\mathrm{bar}=200 \mu \mathrm{m}$ ). (b) Well-differentiated squamous cell carcinoma (bar $=500 \mu \mathrm{m}$ ). (c) Poorly differentiated squamous cell carcinoma ( $\mathrm{bar}=200 \mu \mathrm{m}$ ). (d) Perineural involvement by tumor in a poorly differentiated squamous cell carcinoma $($ bar $=100 \mu \mathrm{m}$ ).

Table 6 Distribution of TERT gene promoter mutations in the study specimens

\begin{tabular}{|c|c|c|c|c|c|c|}
\hline \multirow[b]{2}{*}{ Diagnosis } & \multirow[b]{2}{*}{$N$} & \multicolumn{2}{|c|}{ Classic mutations $^{\mathrm{a}}$} & \multicolumn{3}{|c|}{ Non-classic mutations } \\
\hline & & Number (\%) & Homozygous $(\%)^{\mathrm{b}}$ & Number (\%) & Homozygous $(\%)^{\mathrm{b}}$ & Co-occurrence ${ }^{\mathrm{C}}$ \\
\hline Sporadic basal cell carcinoma & 23 & $18(78 \%)$ & $15(83 \%)$ & $8(35 \%)$ & $5(62 \%)$ & $6(75 \%)$ \\
\hline Nevoid basal cell carcinoma syndrome & 19 & $13(68 \%)$ & $12(92 \%)$ & $5(26 \%)$ & $3(60 \%)$ & $4(80 \%)$ \\
\hline Squamous cell carcinoma & 26 & $13(50 \%)$ & $8(62 \%)$ & $5(19 \%)$ & $3(60 \%)$ & $2(40 \%)$ \\
\hline Bowen's disease & 11 & $1(9 \%)$ & $1(100 \%)$ & $1(9 \%)$ & 0 & 0 \\
\hline Benign & 15 & 0 & NA & 1 & 0 & NA \\
\hline
\end{tabular}

Abbreviations: N, total number of specimens; NA, not applicable.

aThe classic mutations are $-124 \mathrm{C}>\mathrm{T},-146 \mathrm{C}>\mathrm{T}$, and the double mutations $-124 /-125 \mathrm{CC}>\mathrm{TT}$ and $-138 /-139 \mathrm{CC}>\mathrm{TT}$.

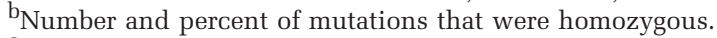

${ }^{\mathrm{C}}$ Number and percent of specimens with a non-classic mutation that also had a classic mutation.

high frequency of the $-101 \mathrm{C}>\mathrm{T}$ mutation in BCC, it may be worthy of further investigation with functional studies. Interestingly, we also found a heterozygous $-126 \mathrm{C}>\mathrm{T}$ mutation in one of the two hemangiomas studied. This is a preliminary finding that also may be worthy of further investigation.

Although we did not have germline DNA from the patients to directly determine whether the 

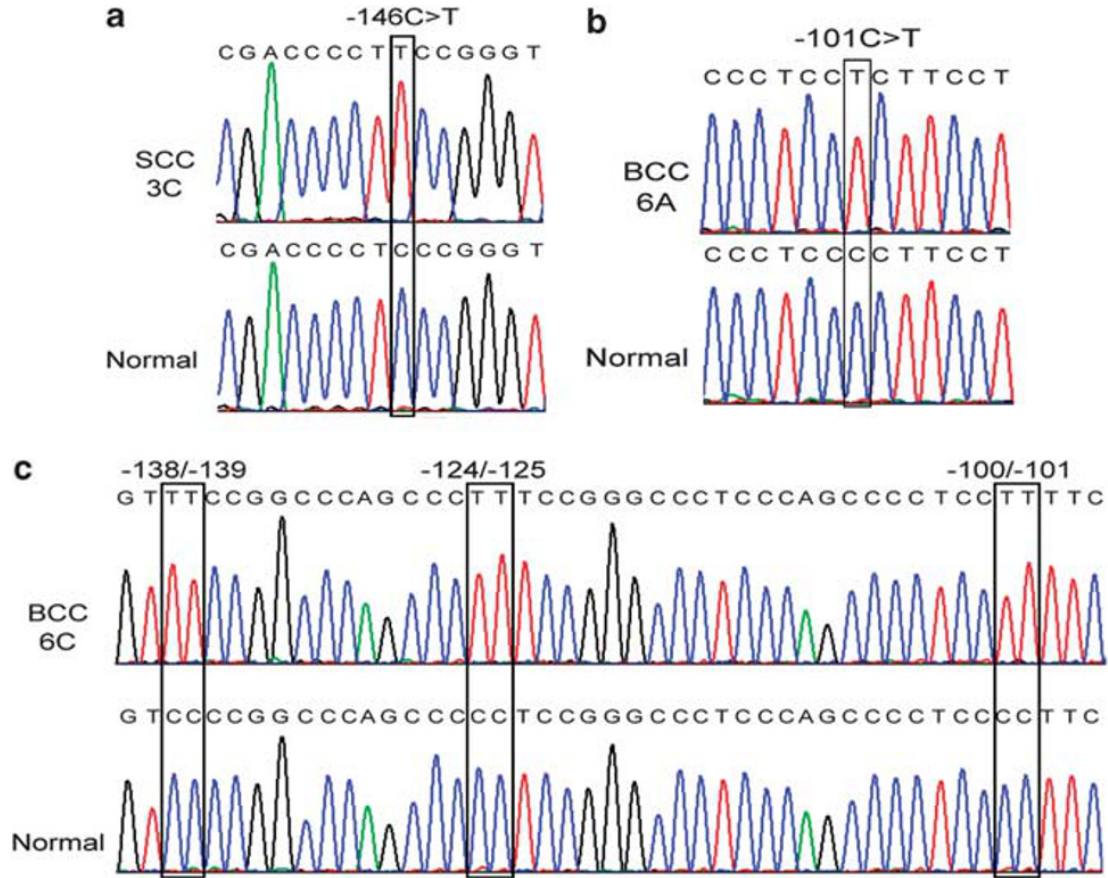

Figure 2 Sanger sequencing results showing several of the mutations found in the TERT promoter. (a) A homozygous $-146 \mathrm{C}>\mathrm{T}$ mutation in squamous cell carcinoma SCC 3C (Table 3). (b) A homozygous -101C $>$ T mutation in sporadic basal cell carcinoma BCC 6A (Table 1). (c) A homozygous - 124/-125CC > TT, - 138/-139CC > TT, and - 100/ - 101CC > TT from sporadic basal cell carcinoma BCC 6C (Table 1).

mutations were somatic, the detection of discordant mutations in multiple tumors from the same patient is consistent with a somatic origin. This conclusion is also consistent with results on TERT promoter mutations in melanoma and glioma, which have also been shown to be somatic. ${ }^{17,18,20}$

The majority of mutations were homozygous or hemizygous with all, or almost all, of the signal representing the mutant nucleotide (Table 6). This novel finding may have been overlooked previously due to differences in tumor purity between studies (contaminating normal cells in tumor samples would make detection of a homozygous mutation difficult) or may be a unique feature of these tumors. We speculate that the apparent homozygosity is due to mitotic recombination, a common event resulting in loss of the normal copy of tumor-suppressor genes and oncogenes, ${ }^{22-24}$ which would likely cause even greater TERT activation than having only one copy with an activating mutation. For the TERT promoter, there may be selection for even greater expression than can be supported by an activating mutation in one copy alone. Alternative explanations include deletion of a nearby tumor suppressor, or a gene conversion event. Further studies will be needed to determine the cause of the homozygosity observed in these tumors.

To summarize, we show that the somatic activating mutations in the TERT promoter, initially identified in melanoma, are also frequently present in the two most common types of skin cancer, basal cell and squamous cell carcinoma. The mutations are consistent with UV radiation mutagenesis, and are very frequently homozygous. The high recurrence of these mutations in skin cancer, as well as several other types of cancer, ${ }^{17,18,20}$ suggests that they are significant, and may have a role in initiation or progression of both melanoma and nonmelanoma skin cancer. Considering the importance of maintaining telomere length in the pathogenesis of cancer, ${ }^{19}$ and the role of telomerase in carrying out this function in normal cells, ${ }^{13}$ we suspect that the TERT promoter mutations contribute to carcinogenesis by increasing expression of telomerase. ${ }^{17,18}$ However, functional studies, beyond the scope of this report, including reporter and transformation assays, are necessary to test this. Because of the high frequency of basal cell carcinoma in the human population, and the identification of TERT promoter mutations in the majority of these tumors, these mutations may be the most common cancer-associated mutations yet discovered.

\section{Acknowledgements}

This work was supported by the Departments of Dermatology and Pathology. We thank Nufatt Leong for help with the experiments and Hartmut Land, $\mathrm{PhD}$ for helpful discussions.

\section{Disclosure/conflict of interest}

The authors declare no conflict of interest. 


\section{References}

1 Guy GP Jr, Ekwueme DU, Tangka FK, et al. Melanoma treatment costs: A systematic review of the literature, 1990-2011. Am J Prev Med 2012;43:537-545.

2 Kwasniak LA, Garcia-Zuazaga J. Basal cell carcinoma: evidence-based medicine and review of treatment modalities. Int J Dermatol 2011;50:645-658.

3 Reeder AI, Jopson JA, Gray A. Sun protection policies and practices in New Zealand primary schools. N Z Med J 2012;125:70-82.

4 De Zwaan SE, Haass NK. Genetics of basal cell carcinoma. Australas J Dermatol 2010;51:81-92.

5 Ling G, Ahmadian A, Persson A, et al. PATCHED and p53 gene alterations in sporadic and hereditary basal cell cancer. Oncogene 2001;20:7770-7778.

6 Ratushny V, Gober MD, Hick R, et al. From keratinocyte to cancer: the pathogenesis and modeling of cutaneous squamous cell carcinoma. J Clin Invest 2012;122:464-472.

7 Tsatsou F, Trakatelli M, Patsatsi A, et al. Extrinsic aging: UV-mediated skin carcinogenesis. Dermatoendocrinology 2012;4:285-297.

8 Young C. Solar ultraviolet radiation and skin cancer. Occup Med (Lond) 2009;59:82-88.

9 Brash DE, Rudolph JA, Simon JA, et al. A role for sunlight in skin cancer: UV-induced p53 mutations in squamous cell carcinoma. Proc Natl Acad Sci USA 1991;88:10124-10128.

10 Ziegler A, Leffell DJ, Kunala S, et al. Mutation hotspots due to sunlight in the p53 gene of nonmelanoma skin cancers. Proc Natl Acad Sci USA 1993;90:4216-4220.

11 Wolter M, Reifenberger J, Sommer C, et al. Mutations in the human homologue of the Drosophila segment polarity gene patched (PTCH) in sporadic basal cell carcinomas of the skin and primitive neuroectodermal tumors of the central nervous system. Cancer Res 1997;57:2581-2585.

12 Heitzer E, Lassacher A, Quehenberger F, et al. UV fingerprints predominate in the PTCH mutation spec- tra of basal cell carcinomas independent of clinical phenotype. J Invest Dermatol 2007;127:2872-2881.

13 Günes C, Rudolph KL. The role of telomeres in stem cells and cancer. Cell 2013;152:390-393.

14 Boldrini L, Loggini B, Gisfredi S, et al. Evaluation of telomerase in non-melanoma skin cancer. Int J Mol Med 2003;11:607-611.

15 Chen Z, Smith KJ, Skelton HG 3rd, et al. Telomerase activity in Kaposi's sarcoma, squamous cell carcinoma, and basal cell carcinoma. Exp Biol Med (Maywood) 2001;226:753-757.

16 Parris CN, Jezzard S, Silver A, et al. Telomerase activity in melanoma and non-melanoma skin cancer. Br J Cancer 1999;79:47-53.

17 Horn S, Figl A, Rachakonda PS, et al. TERT promoter mutations in familial and sporadic melanoma. Science 2013;339:959-961.

18 Huang FW, Hodis E, Xu MJ, et al. Highly recurrent TERT promoter mutations in human melanoma. Science 2013;339:957-959.

19 Hanahan D, Weinberg RA. Hallmarks of cancer: the next generation. Cell 2011;44:646-674.

20 Killela PJ, Reitman ZJ, Jiao Y, et al. TERT promoter mutations occur frequently in gliomas and a subset of tumors derived from cells with low rates of selfrenewal. Proc Natl Acad Sci USA 2013;110:6021-6026.

21 Pfeifer GP, Besaratinia A. UV wavelength-dependent DNA damage and human non-melanoma and melanoma skin cancer. Photochem Photobiol Sci 2012;11:90-97.

22 Baxter EJ, Scott LM, Campbell PJ, et al. Acquired mutation of the tyrosine kinase JAK2 in human myeloproliferative disorders. Lancet 2005;365: 1054-1061.

23 Tischfield JA. Loss of heterozygosity or: how I learned to stop worrying and love mitotic recombination. Am J Hum Genet 1997;61:995-999.

24 Zhu X, Dunn JM, Goddard AD, et al. Mechanisms of loss of heterozygosity in retinoblastoma. Cytogenet Cell Genet 1992;59:248-252. 